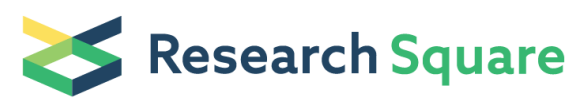

Preprints are preliminary reports that have not undergone peer review.

They should not be considered conclusive, used to inform clinical practice,

or referenced by the media as validated information.

\title{
Renal tumors: Age spectrum and histological distribution across childhood
}

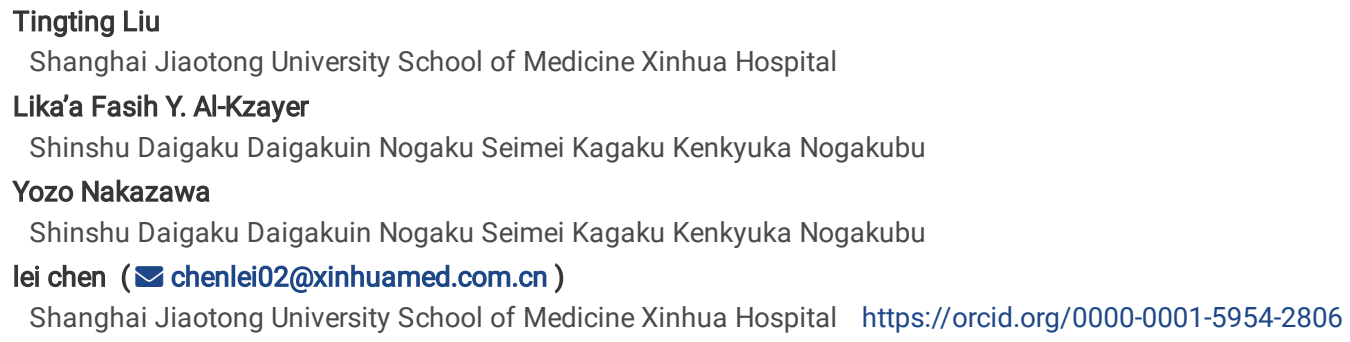

\section{Research}

Keywords: Renal tumors, Childhood, Age, Histological types

Posted Date: August 10th, 2020

DOI: https://doi.org/10.21203/rs.3.rs-54837/v1

License: @ (i) This work is licensed under a Creative Commons Attribution 4.0 International License. Read Full License 


\section{Abstract}

Background: The objective of this study was to identify the relationship between the histopathological distribution of renal tumors and the age parameter across childhood period and to compare that with the available literature.

Methods: A total of 193 pediatric patients with renal tumors were classified into 5 groups as embryo, infant, early childhood, childhood, and adolescent. Age distribution, pathological types and clinical characteristics were summarized.

Results: Among the 193 patients, 95.8\% presented with malignant tumors, and 4.2\% showed benign tumors. The prevalence of Wilms' tumor (WT( and nonWT, were $63.7 \%$ and $36.3 \%$, respectively. Non-WT patients included clear cell sarcoma of the kidney (CCSK), followed by rhabdoid tumor of the kidney (RTK), congenital mesoblastic nephroma (CMN), cystic partially differentiated nephroblastoma (CPDN), and renal cell carcinoma (RCC). Early childhood (89/193, 46.2\%) was the most common period of onset, followed by infant (73/193, 37.9\%), childhood (19/193, 9.8\%), embryo (8/193, 4.1\%) and adolescent (4/193, $2.0 \%)$. WT predominantly occurred in infant and early childhood and decreased among older age group. Non-WT occurred various period of onset and rather common during embryo. $10.9 \%$ of patients were asymptomatic at the time of diagnosis and that was significantly observed in non-WT ( $P=0.04)$.

Conclusions: Age of onset is a highly significant factor for pediatric renal tumors. Relationship between age spectrum and pathological characteristics influences distinguishing the histopathological distribution of WT and non-WT.

\section{Background}

Pediatric renal tumors account for nearly $7 \%$ of all childhood cancers. Renal tumors represent heterogenous histopathological subtypes, including Wilms' tumor (WT) and non-WT. WT also called nephroblastoma, is the most common type of renal tumors in children ${ }^{[1]}$. Non-WT was uncommon, and present a wide histological spectrum, including clear cell sarcoma of the kidney (CCSK), rhabdoid tumor of the kidney (RTK), congenital mesoblastic nephroma (CMN), cystic partially differentiated nephroblastoma (CPDN), renal cell carcinoma (RCC), and several other rare types ${ }^{[2,3]}$.

Age and gender-related differences of tumor behavior exist in the heterogeneous subtypes of renal tumors. Renal tumors occur throughout the periods of pediatric growth and development, moreover histopathological distribution and clinical features differ in each period of childhood ${ }^{[4]}$. However, because of the heterogeneity, descriptive data on age patterns and particular-histopathological type in childhood is limited.

Non-WT comprise represent a small proportion of all childhood cancers ${ }^{[5]}$. Due to its rarity, non-WT behavior has not been fully understood and sometimes causes misdiagnoses. Clinical features and histopathological types among non-WT might be related to age distribution ${ }^{[6-7]}$. CMN present with high prevalence in the first 2 months of life, with an excellent prognosis overall ${ }^{[7]}$. However, the relationship between age spectrum and histopathological types of all renal tumors is unclear across childhood.

In this study, we evaluated the differences in histopathological distribution of pediatric renal tumors, and moreover compared the clinicopathological characteristics between WT and of non-WT.

\section{Methods}

A total of 193 pediatric patients with renal tumors were retrospectively reviewed between 2012 and 2018 from a single institution. Clinical data, including age of onset, gender, symptoms and lesion sites, were retrieved from medical records.

\section{Age grouping}

The 193 pediatric patients were classified into 5 groups including embryo, infant ( $0-\leq 2$ years), early childhood ( $2-\leq 6$ years), childhood ( $6-\leq 12$ years), and adolescent (12- $\leq 14$ years). Moreover, we subclassified these groups by 1 -year interval.

\section{Imaging assessments}

Tumor lesions were identified by imaging assessments, such as ultrasonography, computed tomography, magnetic resonance imaging, or fluorodeoxyglucose positron emission tomography-scan.

\section{Histological and immunohistochemistry analyses}

Hematoxylin and eosin-stained sections from routinely fixed, paraffin-embedded tissues were examined. Histopathological diagnoses were established according to morphological, immunohistochemical evaluations, and/or cytogenetic study. The pathological diagnoses were based on the criteria of WHO Classification of Tumors of the Urinary System and Male Genital Organs World Health Organization classification [9].

\section{Statistical analysis}

Contingency tables were analyzed using Pearson Chi-square statistic. Differences with $P$-value $<0.05$ were regarded as statistically significant. The software of SPSS version 17.0 (SPSS Inc., Chicago, IL, USA) was used for statistical calculations.

\section{Results}




\section{Histological types of pediatric renal tumors}

As shown in Table 1, a total of 193 patients with renal tumors were diagnosed as WT (123/193, 63.7\%) and non-WT (70/193, 36.3\%). Based on tumor biology, $95.8 \%$ of patients (185/193) presented with malignant tumors, and $4.2 \%$ of patients (8/193) with benign tumors. Malignant non-WT was distributed to the following types, CCSK, RTK, CMN, RCC, CPDN, unclassified sarcoma, and primitive neuroectodermal tumor (PNET), with a frequency of (26/185, 14.1\%), (9/185, 4.9\%), (8/185, 4.3\%), (7/185, 3.8\%), (6/185, 3.2\%), (5/185, 2.7\%), and (1/185, 0.5\%), respectively. Benign non-WT included cystic nephroma, ossifying renal tumor, metanephric adenoma, hemangioma, and lymphangioma in $4,1,1,1$, and 1 patient, respectively.

\section{Age distribution}

Age of onset ranged from fetal period to 14 years of age among the 193 patients. There were $8,34,39,35,21,17,16,7,4,2,3,2,1,3$ and 1 patient in each age groups of embryo, $0-\leq 1$ year, $1-\leq 2$ years, $2-\leq 3$ years, $3-\leq 4$ years, $4-\leq 5$ years, $5-\leq 6$ years, $6-\leq 7$ years, $7-\leq 8$ years, $8-\leq 9$ years, $9-\leq 10$ years, $10-\leq 11$ years, $11-$ $\leq 12$ years, $12-\leq 13$ years, and $13-\leq 14$ years, respectively (Figure 1 ). The 193 patients with renal tumors commonly occurred in early childhood (89/193, $46.2 \%)$, followed by infant $(73 / 193,37.9 \%)$, childhood (19/193, 9.8\%), embryo $(8 / 193,4.1 \%)$ and adolescent $(4 / 193,2.0 \%)$.

\section{Age distribution and histological subtypes}

As shown in Figure 2 and 3, WT (123 patients) were predominantly diagnosed during infant and early childhood, and decreased in proportion with increasing in age, whereas the non-WT (70 patients) variably occurred across different period. CCSK patients occurred from 3 months to 8 years, with a peak incidence rate in $1-\leq 2$ years $(9 / 26,34.6 \%)$. RTK patients commonly occur during infancy and become rare in early childhood. Five out of $8 \mathrm{CMN}$ patients were found in embryo, and the other 3 patients were made diagnostic delay within 1 year of age. RCC patients ranged from 2 to 13 years of age. CPDN patients ranged from 4 to 22 months, and absolutely occurred in infant. Patients with unclassified sarcomas were identified mostly in infant and early childhood.

During the fetal period, CMN, WT and hemangioma were found in 5, 2, and 1 fetus, respectively, from 28 to 38 weeks of gestational age. During early childhood, the most cases presented with WT (68/89), followed by CCSK (10/89), RCC (3/89), sarcoma (3/89), RTK (2/89), cystic nephroma (2/89), and metanephric adenoma (1/89). Non-WT patients occurred more frequently during fetal period $(6 / 70$ vs. $2 / 123, P=0.02)$, whereas WT was diagnosed more frequently during early childhood (68/123 vs. $21 / 70, P=0.001)$.

\section{Clinical features and comparison between WT and non-WT}

There were 99 boys and 94 girls among the total patients, with no significant difference between WT and non-WT groups. Among non-WT patients, male gender was predominant in $\operatorname{CCSK}(M: F=17: 9)$ and $\operatorname{CPDN}(M: F=5: 1)$, whereas prevalence of female was shown in $R C C(M: F=2: 5)$ and $R T K(M: F=4: 5)$.

As shown in Table 1, 10.9\% of patients were asymptomatic at the time of diagnosis, and that was significantly more common in non-WT patients than WT patients $(P=0.04)$. Abdominal distension was the most common symptom, followed by hematuria, abdominal pain, vomiting, frequent urination and hypertension. Concerned with the location of tumors, left kidney, right kidney, and both kidneys were involved in 95 (95/193, 49.2\%), 96 (96/193, 49.7\%) and 2 $(2 / 193,1.1 \%)$ patients, respectively. There was no significant difference between WT and non-WT patients.

\section{Discussion}

Pediatric renal tumors commonly present with various clinical symptoms and radiological findings. Differential diagnoses before surgery among heterogeneous histopathological subtypes represent a great challenge for clinicians.

WT is the most common renal tumor encountered in the total series of our patients, $63.7 \%$, comparable to that reported in Bozlu et al. $68.8 \%{ }^{[10]}$, and Chan et al. $64.7 \%{ }^{[11]}$. WT commonly occurs in those younger than 5 years of age, and most of patients are diagnosed within the age ranging from 1 to 4 years ${ }^{[1]}$. In our study, WT was reported more frequently across infancy and early childhood, with a peak at the age range of $2-\leq 3$ years.

Non-WT cases occur less frequently among pediatric renal tumors, and accounts for less than $1 \%$ of all pediatric cancers ${ }^{[12]}$. The prevalence of non-WT in our series of renal tumors was $36.3 \%$ comparable to that of previous Asian report ${ }^{[13]}$ of $35.7 \%$, whereas, American report showed a much lower prevalence of nonWT of less than $10 \%{ }^{[12]}$. Non-WT represents heterogenous group of renal tumors, that present with diagnostic and treatment challenges, especially in regions where therapeutic protocols are applied before obtaining a histopathological diagnosis.

Age tendency presents an important parameter in distinguishing subtypes of non-WT in childhood. In our series, high proportion of non-WT patients (75\%) were found in embryo, and the higher frequency of $\mathrm{CMN}$ could explain the significant difference. $\mathrm{CMN}$ is a rare tumor with a low malignant potential. In our study, CMN cases comprised $4.1 \%$, comparable to the reported frequency of $3.5 \%$ among all pediatric renal neoplasms ${ }^{[14]}$. CMN most commonly occurs early in infancy and rare cases are detected prenatally ${ }^{[15]}$. Of note, 5 out of $8 \mathrm{CMN}$ patients were initially detected as an abdominal mass prenatally by ultrasonography and/or magnetic resonance imaging (MRI) in the current study.

As previously described, CCSK is observed as an aggressive renal sarcoma in childhood and mostly in children under 3 years of age ${ }^{[16]}$. Similarly, in our series of cases, CCSK occurred from 3 months to 8 years, with a peak incidence rate in $1-\leq 2$ years. CCSK is distinguished from WT by its proclivity to metastasize to bone and other unusual sites, such as the soft tissues or the orbit ${ }^{[17]}$. In our study, $19.2 \%$ of CCSK patients initially present with bone metastasis.

CPDN is considered as a very rare tumor, being recognized as a relatively benign tumor with low malignant potential ${ }^{[18]}$. Our current study, in agreement with the previously reported literature, showed a low frequency of $3.1 \%$ for CPDN, with a prevalence during infancy ${ }^{[19]}$. CPDN occurs during infancy and usually 
affects the age ranging from 6 to 22 months, which distinctively differs from other renal tumors. Of note, the outcome of CPDN is favorable, regardless of the clinical stage or therapeutic protocols.

RTK, a rare aggressive cancer occurring in infancy and early childhood ${ }^{[20]}$. Comparably, our RTK patients ranged from 9 months to 11 years of age, and mostly occurred during infancy. Tomlinson et al, demonstrated that the younger the age of diagnosis of RTK, higher tumor stage and the presence of a CNS lesion were factors predictive of a poor survival rate ${ }^{[21]}$.

The frequency of RCC among our total series of 3.6\% was slightly lower than that of $4.3 \%$ by Silberstein et al ${ }^{\text {[22] }}$. Notably, the patients enrolled in this study were less than 14 years of age, whereas other reports evaluated more adolescent patients with a median age at diagnosis ranging from 9 to 12 years. Pediatric RCC, has been characterized by microphthalmia transcription factor (MiTF) -TFE3 family translocation, which was also belong to the Xp11.2 translocation RCC ${ }^{[23]}$. Likewise, in our study, 6 out of 7 patients were diagnosed as MiTF/TFE3 family translocation-associated carcinoma.

Renal primary sarcomas are a rare group of renal tumors. PNET of the kidney is distinctly rare and aggressive neoplasm that predominantly affects young adults, with $75 \%$ of patients aged $10-39$ years ${ }^{[24]}$. In the present study, our patient who was diagnosed with PNET was 13 years and 7 months age.

Cystic nephroma is an uncommon benign renal tumor occurs during infancy, early childhood and in adult women ${ }^{[25]}$. Sometimes, cystic nephroma and CPDN are indistinguishable on gross examination. In our study, the age of onset discriminates cystic nephroma from CPDN. Moreover, DICER1 mutations are reported as the major genetic event in the development of cystic nephroma ${ }^{[26]}$. Taken together, age factor is shown to be the most important clinical parameter for distinguishing between histopathological types in pediatric renal tumors.

Overall, $10.9 \%$ of patients were asymptomatic, with non-WT patients being significantly higher in this issue compared to WT cases. The high frequency of CMN detected prenatally tended to cause the high proportion of asymptomatic patients.

The limitation of this study is the limited number of cases from a single institution and being among patients of less than 14 years of age. More detailed studies are needed to understand the renal tumors in different age categories.

\section{Declarations}

\section{Authors' contributions}

TL designed the study and wrote the manuscript; LC provided clinical data and performed all pathological analysis; LFA, YN and LC supervised the research and revised the manuscript. All authors have read and approved the final version of the manuscript.

\section{Funding}

Not applicable

\section{Ethics approval and consent to participate}

Ethical approval for the study was obtained from the ethics committee of Xinhua Hospital (Shanghai, China) and the exemption from informed consent was approved as well.

\section{Consent for publication}

Not applicable.

\section{Competing interests}

The authors declare that they have no competing interests.

\section{References}

1. Doganis D, Panagopoulou P, Tragiannidis A, Vichos T, Moschovi M, Polychronopoulou S, Rigatou E, Papakonstantinou E, Stiakaki E, Dana H, Bouka P, Antunes L, Bastos J, Coza D, Demetriou A, Agius D, Eser S, Ryzhov A, Sekerija M, Trojanowski M, Zagar T, Zborovskaya A, Perisic SZ, Strantzia K, Dessypris N, Psaltopoulou T, Petridou ET. Survival and mortality rates of Wilms tumour in Southern and Eastern European countries: Socioeconomic differentials compared with the United States of America. Eur J Cancer. 2018 Sep;101:38-46. doi: 10.1016/j.ejca.2018.06.012. Epub 2018 Jul 17. PubMed PMID: 30014973.

2. Saula PW, Hadley GP. Pediatric non-Wilms' renal tumors: a third world experience. World J Surg. 2012 Mar;36(3):565-72. doi:10.1007/s00268-011-14102. PubMed PMID: 22270981.

3. Zhuge Y, Cheung MC, Yang R, Perez EA, Koniaris LG, Sola JE. Pediatric non-Wilms renal tumors: subtypes, survival, and prognostic indicators. J Surg Res. 2010 Oct;163(2):257-63. doi: 10.1016/j.jss.2010.03.061. Epub 2010 Apr 21. PubMed PMID: 20538287.

4. Cost NG, DeFoor WR Jr, Crotty EJ, Geller JI. The initial experience with RENAL Nephrometry in children, adolescents, and young adults with renal tumors. Pediatr Blood Cancer. 2014 Aug;61(8):1434-9. doi:10.1002/pbc.25027. Epub 2014 Mar 9. PubMed PMID: 24610879. 
5. Ahmed HU, Arya M, Levitt G, Duffy PG, Sebire NJ, Mushtaq I. Part II. Treatment of primary malignant non-Wilms' renal tumours in children. Lancet Oncol. 2007 Sep;8(9):842-8. Review. PubMed PMID: 17765193.

6. van den Heuvel-Eibrink MM, Grundy P, Graf N, Pritchard-Jones K, Bergeron C, Patte C, van Tinteren H, Rey A, Langford C, Anderson JR, de Kraker J. Characteristics and survival of 750 children diagnosed with a renal tumor in the first seven months of life: A collaborative study by the SIOP/GPOH/SFOP, NWTSG, and UKCCSG Wilms tumor study groups. Pediatr Blood Cancer. 2008 Jun;50(6):1130-4. PubMed PMID: 18095319.

7. Glick RD, Hicks MJ, Nuchtern JG, Wesson DE, Olutoye OO, Cass DL. Renal tumors in infants less than 6 months of age. J Pediatr Surg. 2004 Apr;39(4):522-5. Review. PubMed PMID: 15065020.

8. European Medicines Agency. Reflection Paper: Formulations of Choice for the Paediatric Population, London, 28 July 2006.

9. Moch H, Humphrey PA, Ulbright TM, Cubilla AL, Reuter VE. WHO Classification of Tumours of the Urinary System and Male Genital Organs. Fourth edition. Lyon, France: International Agency for Research on Cancer; 2016.https://apps.who.int/bookorders/anglais/detart1.jsp? codlan $=1 \&$ codcol $=70 \&$ codcch $=4008$.

10. Bozlu G, Çıtak E. Evaluation of renal tumors in children. Turk J Urol. 2018 May;44(3):268-73. doi:10.5152/tud.2018.70120. Epub 2018 May 1. PubMed PMID:29733801; PubMed Central PMCID: PMC5937647.

11. Chan CC, To KF, Yuen HL, Shing Chiang AK, Ling SC, Li CH, Cheuk DK, Li CK, Shing MM. A 20-year prospective study of Wilms tumor and other kidney tumors: a report from Hong Kong pediatric hematology and oncology study group. J Pediatr Hematol Oncol. 2014 Aug;36(6):445-50. doi: 10.1097/MPH.0000000000000018. PubMed PMID: 25050908.

12. Broecker B. Non-Wilms' renal tumors in children. Urol Clin North Am. 2000 Aug;27(3):463-9. ix. Review. PubMed PMID: 10985146.

13. Koshinaga T, Takimoto T, Oue T, Okita H, Tanaka Y, Nozaki M, Tsuchiya K, Inoue E, Haruta M, Kaneko Y, Fukuzawa M. Outcome of renal tumors registered in Japan Wilms Tumor Study-2 (JWiTS-2): A report from the Japan Children's Cancer Group (JCCG). Pediatr Blood Cancer. 2018 Jul;65(7):e27056. doi: 10.1002/pbc.27056. Epub 2018 Apr 6. PubMed PMID: 29630767.

14. England RJ, Haider N, Vujanic GM, Kelsey A, Stiller CA, Pritchard-Jones K, Powis M. Mesoblastic nephroma: a report of the United Kingdom Children's Cancer and Leukaemia Group (CCLG). Pediatr Blood Cancer. 2011 May;56(5):744-8. doi:10.1002/pbc.22871. Epub 2011 Jan 16. PubMed PMID: 21370406.

15. Gooskens SL, Houwing ME, Vujanic GM, Dome JS, Diertens T, Coulomb-l'Herminé A, Godzinski J, Pritchard-Jones K, Graf N, van den Heuvel-Eibrink MM. Congenital mesoblastic nephroma 50 years after its recognition: A narrative review. Pediatr Blood Cancer. 2017 Jul;64(7). doi: 10.1002/pbc.26437. Epub 2017 Jan 26. Review. PubMed PMID: 28124468.

16. Argani P, Perlman EJ, Breslow NE, Browning NG, Green DM, D'Angio GJ, Beckwith JB. Clear cell sarcoma of the kidney: a review of 351 cases from the National Wilms Tumor Study Group Pathology Center. Am J Surg Pathol. 2000 Jan;24(1):4-18. PubMed PMID: 10632483.

17. Gooskens SL, Furtwängler R, Spreafico F, van Tinteren H, de Kraker J, Vujanic GM, Leuschner I, Coulomb-L'Herminé A, Godzinski J, Schleiermacher G, Stoneham S, Bergeron C, Pritchard-Jones K, Graf N, van den Heuvel-Eibrink MM. Treatment and outcome of patients with relapsed clear cell sarcoma of the kidney: a combined SIOP and AIEOP study. Br J Cancer. 2014 Jul;15(2):227-33. 111 ). doi: 10.1038/bjc.2014.291. Epub 2014 Jun 17. PubMed PMID: 24937667; PubMed Central PMCID: PMC4102945.

18. Luithle T, Szavay P, Furtwängler R, Graf N, Fuchs J, SIOP/GPOH Study Group. Treatment of cystic nephroma and cystic partially differentiated nephroblastoma-a report from the SIOP/GPOH study group. J Urol. 2007 Jan;177(1):294-6. PubMed PMID: 17162067.

19. Joshi VV, Beckwith JB. Pathologic delineation of the papillonodular type of cystic partially differentiated nephroblastoma. A review of 11 cases. Cancer. 1990 Oct 1;66(7):1568-77. PubMed PMID: 2169993.

20. Cheng H, Yang S, Cai S, Ma X, Qin H, Zhang W, Fu L, Zeng Q, Wen M, Peng X, Wang H. Clinical and Prognostic Characteristics of 53 Cases of Extracranial Malignant Rhabdoid Tumor in Children. A Single-Institute Experience from 2007 to 2017. Oncologist. 2019 Jul;24(7):e551-e558. doi: 10.1634/theoncologist.2018-0416. Epub 2019 Mar 26. PubMed PMID: 30914466; PubMed Central PMCID: PMC6656446.

21. Tomlinson GE, Breslow NE, Dome J, Guthrie KA, Norkool P, Li S, Thomas PR, Perlman E, Beckwith JB, D'Angio GJ, Green DM. Rhabdoid tumor of the kidney in the National Wilms' Tumor Study: age at diagnosis as a prognostic factor. J Clin Oncol. 2005 Oct 20;23(30):7641-5. PubMed PMID: 16234525.

22. Silberstein J, Grabowski J, Saltzstein SL, Kane CJ. Renal cell carcinoma in the pediatric population: Results from the California Cancer Registry. Pediatr Blood Cancer. 2009 Feb;52(2):237-41. c.21779. PubMed PMID: 18937317.. ( . doi: 10.1002/pb.

23. Spreafico F, Collini P, Terenziani M, Marchianò A, Piva L. Renal cell carcinoma in children and adolescents. Expert Rev Anticancer Ther. 2010 Dec;10(12):1967-78. doi:10.1586/era.10.188. Review. PubMed PMID: 21110762.

24. Ellinger J, Bastian PJ, Hauser S, Biermann K, Müller SC. Primitive neuroectodermal tumor: rare, highly aggressive differential diagnosis in urologic malignancies. Urology. 2006 Aug;68(2):257-62. Review. PubMed PMID: 16904430.

25. Li Y, Pawel BR, Hill DA, Epstein JI, Argani P. Pediatric Cystic Nephroma Is Morphologically, Immunohistochemically, and Genetically Distinct From Adult Cystic Nephroma. Am J Surg Pathol. 2017 Apr;41(4):472-81. S.0000000000000816. PubMed PMID: 28177962; PubMed Central PMCID: PMC5350016.. ; ). doi: 10.1097/PA.

26. Doros LA, Rossi CT, Yang J, Field A, Williams GM, Messinger Y, Cajaiba MM, Perlman EJ, Schultz A, Cathro K, Legallo HP, LaFortune RD, Chikwava KA, Faria KR, Geller P, Dome JI, Mullen JS, Gratias EA, Dehner EJ, Hill LP. DA. DICER1 mutations in childhood cystic nephroma and its relationship to DICER1renal sarcoma. Mod Pathol. 2014 Sep;27(9):1267-80. doi:10.1038/modpathol.2013.242. Epub 2014 Jan 31. PubMed PMID: 24481001; PubMed Central PMCID: PMC4117822.

\section{Tables}


Table 1. Histological distribution of 193 patients with renal tumors in different age groups

\begin{tabular}{|c|c|c|c|c|c|c|c|c|c|c|c|c|c|c|}
\hline \multirow{4}{*}{$\begin{array}{l}\text { Histological } \\
\text { types }\end{array}$} & \multirow{4}{*}{$\begin{array}{l}\text { Embryo } \\
n=8 \\
(4.1 \%) \\
n=8 \\
(4.1 \%)\end{array}$} & \multirow{2}{*}{\multicolumn{2}{|c|}{$\begin{array}{l}\text { Infant } \\
n=73(37.9 \%)\end{array}$}} & \multirow{2}{*}{\multicolumn{4}{|c|}{$\begin{array}{l}\text { Early Childhood } \\
n=89(46.2 \%)\end{array}$}} & \multirow{2}{*}{\multicolumn{6}{|c|}{$\begin{array}{l}\text { Childhood } \\
n=19(9.8 \%)\end{array}$}} & \multirow{2}{*}{$\begin{array}{l}\mathrm{Ac} \\
\mathrm{n}=\end{array}$} \\
\hline & & & & & & & & & & & & & & \\
\hline & & \multirow{2}{*}{$\begin{array}{l}0- \\
\leq 12 m \\
n=34 \\
(17.6 \%)\end{array}$} & \multirow{2}{*}{$\begin{array}{l}1-\leq 2 y \\
n=39 \\
(20.2 \%)\end{array}$} & \multirow{2}{*}{$\begin{array}{l}2-\leq 3 y \\
n=35 \\
(18.1 \%)\end{array}$} & \multirow{2}{*}{$\begin{array}{l}3-\leq 4 y \\
n=21 \\
(10.9 \%)\end{array}$} & \multirow{2}{*}{$\begin{array}{l}4-\leq 5 y \\
n=17 \\
(8.8 \%)\end{array}$} & \multirow{2}{*}{$\begin{array}{l}5-\leq 6 y \\
n=16 \\
(8.2 \%)\end{array}$} & \multirow{2}{*}{$\begin{array}{l}6-\leq 7 y \\
n=7 \\
(3.6 \%)\end{array}$} & \multirow{2}{*}{$\begin{array}{l}7-\leq 8 y \\
n=4 \\
(2.0 \%)\end{array}$} & \multirow{2}{*}{$\begin{array}{l}8-\leq 9 y \\
n=2 \\
(1.0 \%)\end{array}$} & \multirow{2}{*}{$\begin{array}{l}9- \\
\leq 10 y \\
n=3 \\
(1.5 \%)\end{array}$} & \multirow{2}{*}{$\begin{array}{l}10- \\
\leq 11 y \\
n=2 \\
(1.0 \%)\end{array}$} & \multirow{2}{*}{$\begin{array}{l}11- \\
\leq 12 y \\
n=1 \\
(0.5 \%)\end{array}$} & \multirow{2}{*}{$\begin{array}{l}12 \\
\leq \\
n= \\
(1\end{array}$} \\
\hline & & & & & & & & & & & & & & \\
\hline \multicolumn{15}{|l|}{ Malignant tumor } \\
\hline Nephroblastoma & 2 & 17 & 25 & 27 & 18 & 11 & 12 & 5 & 2 & 2 & 1 & & & 1 \\
\hline CCSK & & 3 & 9 & 4 & 1 & 5 & & 2 & 2 & & & & & \\
\hline RTK & & 4 & 1 & 1 & 1 & & & & & & 1 & 1 & & \\
\hline CMN & 5 & 3 & & & & & & & & & & & & \\
\hline $\mathrm{RCC}$ & & & & 1 & & & 2 & & & & 1 & 1 & 1 & 1 \\
\hline CPDN & & 3 & 3 & & & & & & & & & & & \\
\hline Sarcoma & & & 1 & & 1 & 1 & 1 & & & & & & & 1 \\
\hline \multicolumn{15}{|l|}{ PNET } \\
\hline \multicolumn{15}{|l|}{ Benign tumor } \\
\hline $\begin{array}{l}\text { Cystic } \\
\text { nephroma }\end{array}$ & & 2 & & 1 & & & 1 & & & & & & & \\
\hline ORTI & & 1 & & & & & & & & & & & & \\
\hline EA & & & & 1 & & & & & & & & & & \\
\hline Haemangioma & 1 & & & & & & & & & & & & & \\
\hline Lymphangioma & & 1 & & & & & & & & & & & & \\
\hline
\end{tabular}

CCSK, clear cell sarcoma of the kidney; CMN, congenital mesoblastic nephromas; CPDN, cystic partially differentiated nephroblastoma; EA, Etanephric adenoma; ORTI, ossifying renal tumor of infancy; PNET, primitive neurotodermal tumour, RCC, renal cell carcinoma.

\section{Figures}




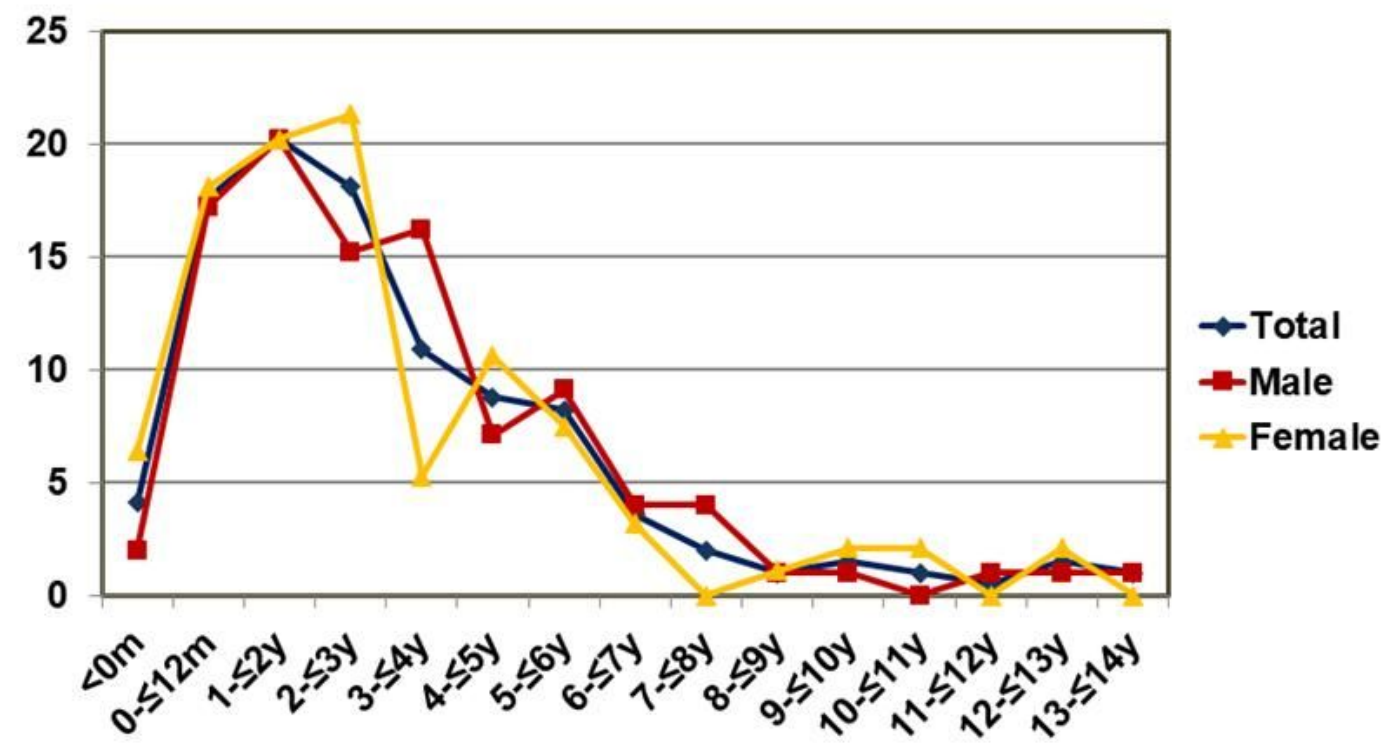

Figure 1

Age and gender-specific incidence of pediatric renal malignant tumors by 1-year age groups.

Histological Distribution of

185 patients with malignant renal tumors in

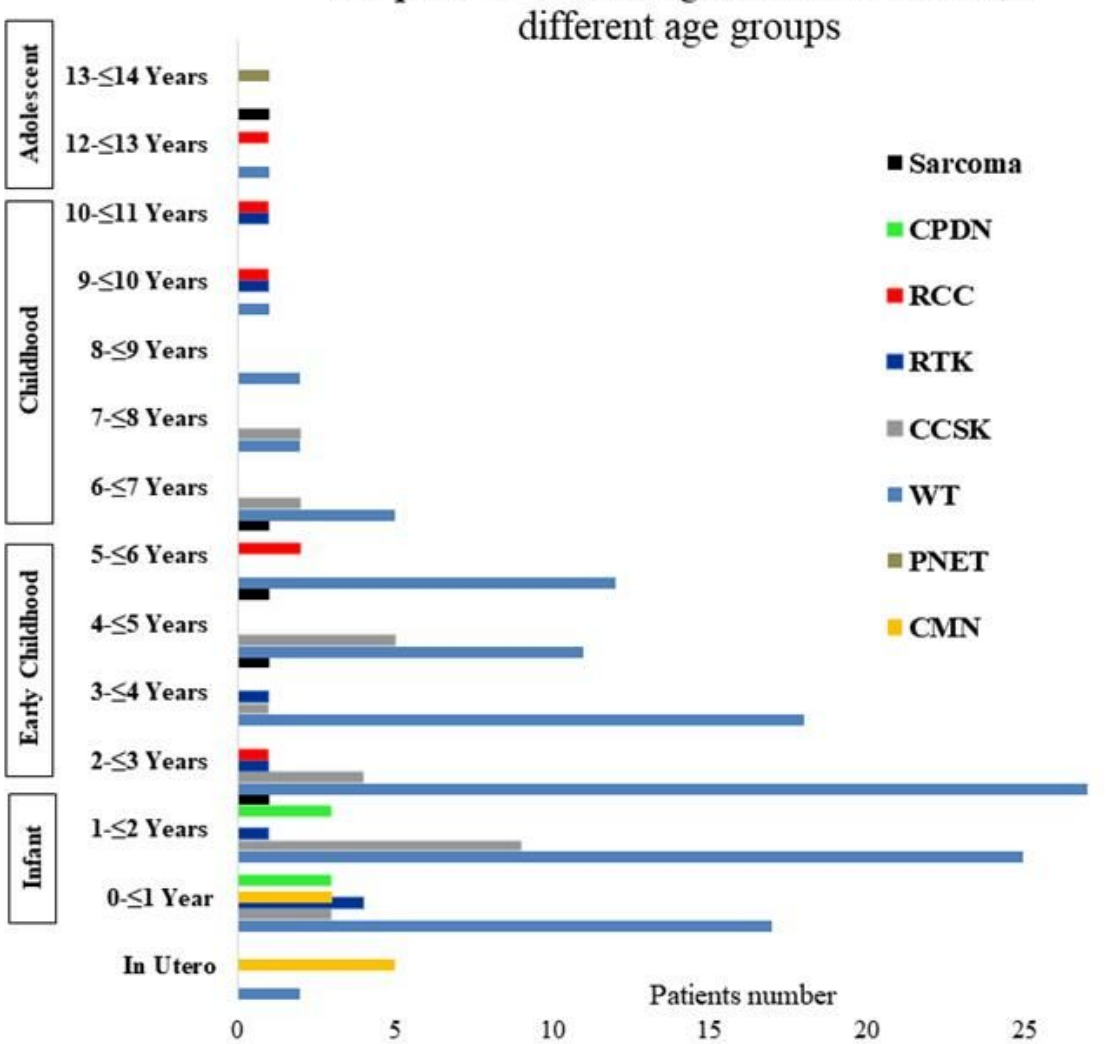


Figure 2

Histological distribution of 185 patients with malignant renal tumors in different age groups.

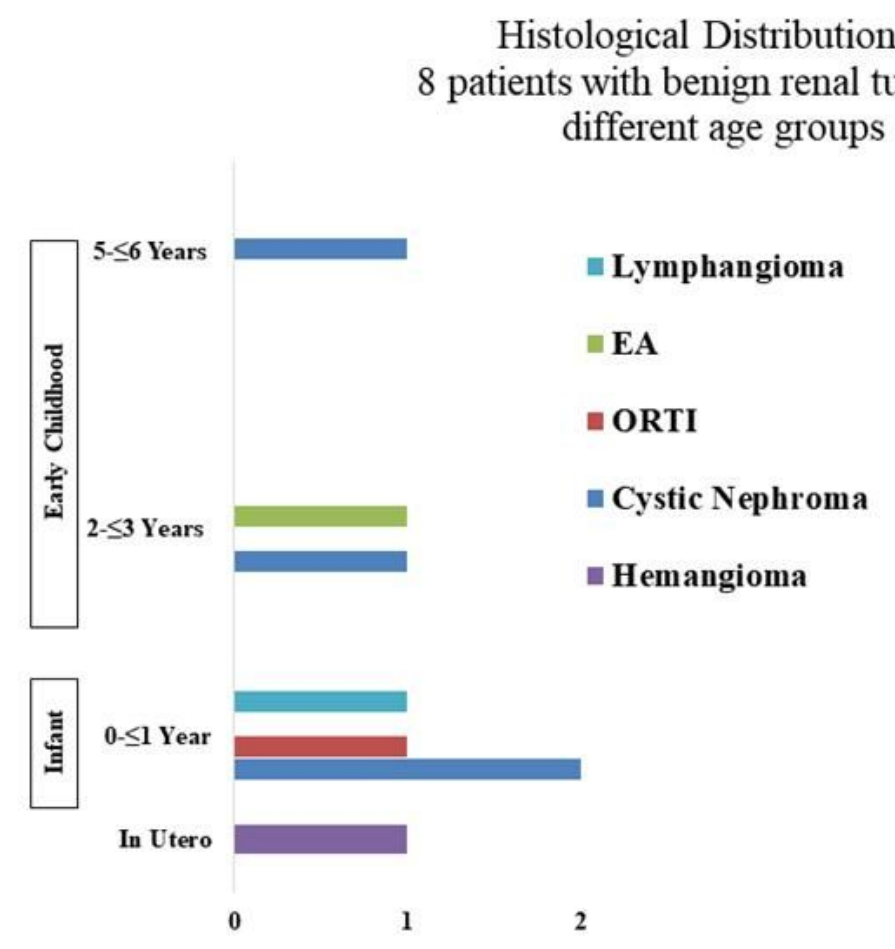

Figure 3

Histological distribution of 8 patients with benign renal tumors in different age groups. 